\title{
Managing public fears: Cold War sorcerers ${ }^{\star}$
}

\author{
M. V.Sinyutin
}

St. Petersburg State University,

7-9, Universitetskaya nab., St. Petersburg, 199034, Russian Federation

Sociological Institute of the Russian Academy of Sciences,

25/14, 7-ya Krasnoarmeyskaya ul., St. Petersburg, 190005, Russian Federation

For citation: Sinyutin M.V. Managing public fears: Cold War sorcerers. Vestnik of Saint Petersburg University. Sociology, 2019, vol. 12, issue 1, pp. 102-108. https://doi.org/10.21638/spbu12.2019.108

The danger of the Cold War is at the public agenda again. Economic crisis at the early years of the $21^{\text {st }}$ century had launched the return of Cold War public attitudes. One can find through the media about the starting stage of the Second Cold War. Under capitalism, the politicized media image is replicated like any other commodity - it is important to design a new shell and the stereotyped product will be easier bought and consumed.

American social thinkers, who are specialists on US military policy and the anti-war movement, Jeremy Kuzmarov and John Marciano wrote a book that echoes the growing public concern of potential danger in case if new Cold War begins. The book is not about the Cold War itself, but on the American role in it, how it was designed and had been processed by the U.S. elite. The major focus of the book pointed on the Cold War project as a domestic American product constructed for internal consumption at the market of public policy. "It is designed to deflect public attention from our domestic ills by scapegoating a foreign nation" (171).

Historically the Cold War project was rooted at the times of a Big Deal, and unprecedented success of American labor, left and social democracy movement, that occurred during the presidency of Franklin Roosevelt. We know from the history of the Soviet Union how militarization hits the democracy under a socialist system, but an example of the United States shows further reaching outcomes. Jeremy Kuzmarov and John Marciano show through the pages of the book how "anti-Communist paranoia resulted in the spread of political repression" (167). American arms producers have aimed to maintain high military spending by means of lobbying, hired-gun think tanks professional experts and corporate media.

Sociologist C. Wright Mills stressed in 1958 that American economic prosperity was underpinned by a war economy. With the high unemployment rate, political elite could only increase military expenditures, which needed to get somehow justified. This need met the corporate capitalist interest to violate the Big Deal. Internal class rival which pursued the left ideology was blamed as a provider of "external danger" falsely imputed to the state that firstly claimed itself to be socialist. Political battles in the USSR could be presented for ignorant Americans as an inevitable upshot of socialism to lack public freedoms.

* Book review: Jeremy Kuzmarov, John Marciano. The Russians are Coming, Again. The First Cold War as Tragedy, the Second as Farce. New York: Monthly Review Press, 2018.

(c) Санкт-Петербургский государственный университет, 2019 
Besides producing the ugly image of Soviets as an enemy could benefit in the global struggle for the Third World nations that just had liberated from the colonial rule and needed to model their future development. It became vital to scare and manipulate the public.

The authors find that more deeply stereotypes and images of Cold War fit the American national identity with its exceptionalism, messianism and righteousness. Those stereotyped fondle the feelings of felicitous ending the clash between superpowers. "Popular mythology depicts the First Cold War as a heroic episode in U.S. history, with a few excesses such as Vietnam, but generally, it was a sound strategy in confronting the "evil" totalitarian empire whose values were completely antithetical to those of the United States" (166). Today after the collapse of the Soviet Union and the current downfall of socialist ideology in Russia American political discourse still appears to be sensitive to the same manipulative practices like the second half of the XX century. And this similarity gives authors some basis for applying historical explanations to the modern stage.

The book consists of six chapters.

The first chapter "Anti-Russian Hysteria in Propaganda and Fact" considers regeneration of the Cold War now not against the Soviet Union but Russia, emphasizing the lingering Russophobic discourse and demonization of the Russian leader Putin and some possible implications. The crucial role and used methods of American media are examined on an example of the prestigious media source that is the New York Times. This media, owned by the Ochs-Sulzberger family benefits from connections in U.S. power elite, corporate advertisers and bank loans. It identifies itself with the liberal political wing, formally supporting centrists among Democratic Party.

The authors demonstrate that before Iraq War started in 2003, New York Times had sketched a rather positive image of Russian president Putin, calling him "Westernizing leader", "skillful, pragmatic, smart manager" with "democratic credentials", "opened to cooperation with the West". But Putin's opposing the Iraqi and his iconic speech in $\mathrm{Mu}$ nich at 2007 showed the independent policy which was stigmatized as a comeback of "expansionism" and "authoritarianism", inherent to the Soviet Union at the times of Cold War. The next steps to the habitual anti-Russian attitudes were made after Putin's blocking American machinations in Ukraine and Syria. Another resonant notorious accusation was Russian interference in American presidential elections. Afterwards, the image of Putin had been adorned by epithets "fascist", "professional thug", "new tsar" and Russia coined as "backward", "autocratic", "expansionist" nation.

The technology of stigmatization used by American media appeared to be based on lies, fake news and hostility. Multiple valid and reasonable cases, mentioned by Jeremy Kuzmarov and John Marciano, illustrate the functioning of this ghoulish technology. Unproved information normally had been delivered by American media as deriving from intelligence, expert or anonymous sources, and treated to be actual evidence. No other source of evidence could be presented. "Instances of quality reporting have been overshadowed by the barrage of pieces painting Putin and Russia in the darkest of hues, which contribute in turn to the popular impression that the Russians are coming, again" (29).

Fear of being cheated seems to be embedded in American policymakers' own habits of scam. The authors gave a perfect corroboration of these habits by NATO expansion in Eastern Europe despite the promise to stay still. American politician Zbigniew Brzezinski shamelessly confessed that Americans had tricked Soviet leader Mikhail Gorbachev on this issue. But at the other end, it turned to trust breaking American tactics for Russians. 
At the second chapter "The time You Sent Troops to Quell the Revolution: The True Origins of the Cold War" the authors had discovered what they consider as the "first blow" in the Cold War at the moment of forgotten American invasion to newly established Soviet Russia in 1918-1920, by violating not just international laws and treaties but its own constitution (without the consent of Congress) and by use of absolutely dehumanized practices of arms implementation. Even the U.S. military commander in Siberia, William S. Graves considered it to be a violation of Russia's sovereignty. The authors suggest that military invasion being interpreted in the U.S. just as an unimportant incident, seems to be an unforgettable memory for Russians and demonstrates them a real military threat. According to the concept of the book, after the Russian Revolution U.S. government and American business wished to tie Soviet economy, militarily or peacefully, to that of the United States. But this tie on the Washington side was designed to be hierarchical in favor of its own. Media had prepared American public to this vision by presenting Russia as a "barbarian bedlam", that need to be civilized by means of the Western help. According to the authors "it is clear that after sending troops to quell the revolution, the Soviets would never again trust the United States, predominantly for good reasons, as later history would prove" (58).

The following chapters equip the reader with a panoramic history of the Cold War, showing a strong belief that it was an avoidable tragedy. The authors recognize the imperatives of class rule that drove the U.S. to expand its hegemony worldwide, the warping of the American economic policy by means of excessive military spending, the purges and witch-hunts, and the Cold War's negative effect on the trade unions, women's movement, and the black community.

The third chapter "Provoking Confrontation: The United States and the Origins of the Cold War" gives the knowledge of the early stages of rising tensions between so-called superpowers of the $20^{\text {th }}$ century. Jeremy Kuzmarov and John Marciano suppose that Cold War project could not be launched under the presidency of Big Deal constructor Franklin Roosevelt due to his political influence and a rather cooperative position towards Soviet Russia. Worth mentioning that Big Deal made it possible under the governmental roof to design a temporary balance of labor and capitalist interests to handle with a severe economic crisis. Therefore, Franklin Roosevelt had become the only four times elected American president in history. The capitalists had paid for this deal by highest taxes ever. And corporative business had cherished and idea of abrogation this treaty. After the death of Franklin Roosevelt in 1945, they had concentrated their efforts on obstruction the progressive Big Dealer, communist sympathizer and former vice-president Henry Wallace, and on the promotion of conservative anti-communist Harry Truman. The authors see the nomination of Harry Truman as vice president over Henry Wallace at the 1944 Democratic Party national convention in Chicago to be a key point of the business battle for U.S. presidency.

The authors insist that although anti-communist media and politicians had spread the believe of Soviets' preparation to hostilities, the USSR thought of just security belt around its borders to ensure peaceful and independent economic development aside from the world-capitalist system, escaping the traditional status of raw materials supplier. This had afforded the Soviet Union to provide rapid industrialization, to increase productivity, mass living standards, improved healthcare and free education. All made the Soviet model attractive in the Third World, which the U.S. government prepared to follow the path of permanent economic dependency. 
American historians, as the book shows, realize this crucial moment as a creation of a new narrative, dominant during the Cold War and designed by American corporate leaders. Harry Truman personally insisted to the public that "the Russians played President Roosevelt for a sucker" (69). This narrative was a kind of simplified vision adapted to the era of consumerism. In this vision, the clear opposition had dominated - good vs evil. First attributes to the U.S. and the second - to USSR. Americans were seen as "being in good faith", "keeping promises", "promoting peace and cooperation", "responsive to the rule of public", while Russians - as "rejecting any ethical value", "recognizing no restrictions", "promoting aggression and domination", "driven by abnormal clique". All this must result in acceptance of U.S. image as "a nation of almost unimaginable perfection" (71).

The created narrative had allowed giant military and anti-communist activity spending of the American state. Atomic bomb project and bombing Japanese cities considered to be the early Cold War investments aimed to signal the Soviet Union about American power. Moving in this vein Harry Truman administration had initiated in 1947 over $\$ 400$ mln assistance to those fighting Communism and in 1948 \$2 bln "Marshall Plan" to protect the European economic recovery for those accepted anti-left policy and ideology. Step by step during the years of Cold War U.S. government had been increasing amounts of money spent on an arms race. Besides they use any opportunity to stop soviet influence and spread of communist ideology all over the globe. The authors quote the former head of secret operations inside the USSR, Harry Rositzke: "We knew what we were doing. It was a visceral business of using any bastard as long as he was anti-Communist" (79).

The fourth chapter "The Cold War and the Attack on U.S. Democracy" offers an explanation of moral erosion that had occurred in American democratic ideology in the second half of the $20^{\text {th }}$ century. According to Jeremy Kuzmarov and John Marciano the Cold War "warped U.S. political culture by institutionalizing a mindset that linked dissenting viewpoints and peace activism with treason, and destroyed the prospects for a viable social democracy with attacks on organized labor and decimation of the ranks of the progressive movements and political left" (84). Dozens of examples collected in the chapter brilliantly prove this basic statement.

The authors remind U.S. president Dwight Eisenhower alarm at 1961 about the dangerous threat to American democracy from the alliance of big business and the military, the alliance being fed up by the Cold War public hysteria. Major beneficiaries of this hysteria were American military contractors like Lockheed, Boeing, Chrysler, General Electric, Hughes Aircraft, and General Dynamics. Stabilizing connections of military business with the government had produced the initialized lobbying, administrative black-budgeting and practices of interfering the elections by capitalist corporations. A giant federal bureaucracy and a new class of national security managers were createB, tipping the political balance between the branches of U.S. power in favor of the executive agencies.

The militarization of American life had severely influenced academia. The authors mind it a horrible turn. Goals and interests of Universities and multiple research hubs had shifted to the problems dictated by the military-industrial complex. Academic practices had been developed in favor of authoritarian decision-making models. Intelligence services had recruited plenty of scholars and controlled much of scientific directions, deteriorating the opportunities of civilian industrial technologies. These specialists had prepared by 1954 a plan to attack the Soviet Union with killing $80 \%$ of its population in 118 major cities, that equals to $60 \mathrm{mln}$ people. In 1960 they planned to kill already $500 \mathrm{mln}$ people of 
the Socialist Block, using strategic nuclear forces. But besides the contemplated atrocities worldwide those plans produced some pretty real budget expenditures. According to the economists' rough estimations, the U.S. government spent on the Cold War, i.e. lost for public purposes, over $\$ 7$ bld during the 1948-1991 period.

From 1950 to 1980 trade union membership had reduced to less than $23 \%$ of the workforce. Taft Hartley Bill adopted at 1947 in the atmosphere of rising military hysteria had symbolized the defeat of labor and termination of the New Deal. The authors cite words of historian Joel Kovel that "principal object of the Cold War was not the Soviets but domestic radicals", that "it was really about the American nation, not the Soviet Union" (100). The only trick was to link American anti-war insurgents with Communist doctrine, deriving from abroad. American Communist Party was successfully ruined. Following anti-Communist investigations, the core of trade unionists was expelled from the Congress of Industrial Organization, the only working body really able to resist the rolling back Big Deal. Communist mentality, unionist spirit and proletarian culture of the Depression era in the United States had been declined, and advertising-based consumerism of business civilization had gotten the go-ahead. Decisive means of victory in a battle for public support were corporate control over American mass media.

The fifth chapter "Truman, McCarthysm, and Domestic Repression" clears up the social nature of Cold War hysteria. Domestic repressions called McCarthysm are shown as a form of populism utilizing anti-intellectualism, xenophobia and status anxiety of certain ethnic groups, like Irish, Germans and Catholics from Eastern Europe. It perfectly fits the U.S. traditional demonization of the "other" as a means of reaffirming national identity and superiority. In the case of Communists it was easy to justify their polarity to pure American identity due to a leftist critique of capitalism. But the practice of demonization appeared to be just imitation of the enemy and assumed overestimation of one's danger. Although the American Communist party totaled 32 thousand members in the $150 \mathrm{mln}$ nation at the mid of the XX century, media presented public a picture of flooding U.S. by Soviet agents from American communists. It served an important role in cleansing within governmental offices without any proof but party membership or even sympathy. Moreover, many who advocated regulatory and redistributive policies were removed from the public service as being suspected in Soviet espionage. The very roots of the left movement in the U.S. were sharply damaged.

The list of the major spy obsession victims, according to the authors, is led by Julius and Ethel Rosenberg, Alger Hiss, Owen Lattimore, and Frank Olson. It also includes the Hollywood Ten - prominent screenwriters and directors, sympathized to Communist ideas and being convicted of perjury. Subsequent political turn of Hollywood out of left had provided corporate business with the most effective image-making weapon in the ideological struggle against interests of labor and Soviets. Consumerist reversal of the film industry had been strengthened by the corporate-lead attack on the radical popular culture of America and the distribution of consumerist values. Leftist Americans were characterized as "social pathology" and "manipulative alien force", and Russians as "downtrodden", "clinically depressed", and "drunkards". Spy films about Soviets trying to steal secrets, sabotage military installations or plot against U.S. Government become a highly prevalent Hollywood genre.

The authors describe domestic repression in the U.S. by mentioning weakened women's movement (Claudia Johns, Elizabeth Gurley Flynn, Betty Friedan), victimized black 
American radicals (Du Bois, Paul Robeson, Martin Luther King), growing protest music like Woody Guthrie, and constant growth of the radical right public.

The sixth chapter "A War on the Global South: The Cold War in the Third World" delves into the Cold War's effect on Third World nations, which suffered from proxy wars and ill-conceived regime substitution operations. According to American historian, William Blum U.S. government had carried out over 70 interventions all over the globe during that period. Another historian Eqbal Ahmad counted the approximate number of $21 \mathrm{mln}$ deaths of these interventions in Third World countries. Jeremy Kuzmarov and John Marciano tell that first military conflicts of the Cold War had happened in Greece and Korea. Later the CIA and the American government had orchestrated military coups in Iran (1953), in Guatemala (1954), in Indonesia (1965), in Chile (1973), as well as the substitution of progressive anti-colonial governments by conservative autocrats in Africa. American failure in Cuba and following "Missile Crisis" caused the large-scale special Latin American program of the U.S. government to prevent the growth of left and socialist movements. The most barbarous military crime of U.S. army appeared to be the Indochina wars, with Vietnam aggression at the core. This war showed absolutely unhuman nature of American style death machinery with one-sided mechanical extermination of the opponents.

The authors open eyes on CIA practice of new torture techniques spread globally by means of special training of foreigners at the International Police Academy in Washington, D.C. To manage this torture practice the U.S. Army School of the Americas had prepared top dictators, including Noriega in Panama, Banzer in Bolivia, Lucas Garcia in Guatemala, Paz Garcia in Honduras, Galtieri in Argentine. "As Soviet repression eased following Stalin's death, studies have shown that unjust imprisonment, torture, and other human rights abuses were far more extensive in so-called free world nations than behind the Iron Curtain, though no congressional representative has proposed and museums to commemorate these victims" [while U.S. Congress sanctioned a $\$ 100 \mathrm{mln}$ Victims of Communism Museum in 1993] (158). Ironically the most fortunate stage of the Cold War show had started with the presidency of former Hollywood actor Ronald Reagan who had internalized the consumerist demand of monsters to indulge own forbidden desires for violence. His rhetoric about an "evil empire" effectively influence the public to support tremendous growth of military budget, with the famous Strategic Defense Initiative ("Star Wars" program). Reagan administration financed $\$ 2,6$ bln CIA project to arm Islamic groups in Afghanistan to resist Soviet penetration in the region. By that project, Americans created a dangerous terrorist force, headed by fundamentalist landlords and heroin traffickers. Years after the U.S. themselves reap the rewards of this project facing global terrorist networks spring from anti-Soviet Afghan groups.

A russophobic discourse of the American public still dominate and easily elicit habitual images and stereotypes. Jeremy Kuzmarov and John Marciano suggest that "the prospects for wide-scale resistance thus remains dim, though hope appears to reside in a younger generation that looks to alternative news sources for information, and is more sympathetic to socialist principles because of the downward mobility they have experienced" (164).

In conclusion, the authors search for ways to escape the Third World War, although not much concrete. They claim the clear lesson for Americans from this history that "Russians have more reasons to fear us than we have to fear them" (168). Listing the reasons, 
they mentioned the US invasion in 1918, encircling the Soviet Union with military bases, initiating provocative policies, expanding NATO, having always higher military spending, interfering internal politics and elections. All these were embedded into the public opinion in reverse - as sacramental Soviet intentions against the US. In reality, during the year 2016, Russia spent for military $\$ 65 \mathrm{bln}$, while US $-\$ 609 \mathrm{bln}$. The authors truly believe that Russia as earlier Soviet Union has been opened to diplomatic engagement with the US. They propose to shift an approach from prejudice and suspicious attitude and develop alternative programs.

The concept, proposed in the book, focus the reader on one side of the Cold War standoff. Processes that had taken place in the Soviet Union, as well as those today in Russia, are seeing pretty superficially. Nevertheless, the Russian reader may find this unilateralism quite useful since the other side of this process already has presented in his mind.

Unfortunately, Jeremy Kuzmarov and John Marciano did not consider the essential difference between the First Cold War and nowadays. Originally there was a deep link with the Big Deal situation and demise of business interests under labor and left pressure, that logically ended in claiming the socialist Soviet Union to be a principal rival. Today there is now such a link, and Russia represent specific but capitalist, bourgeois state, without any ideological contradiction to the U.S. The core is now in competition between two capitalist powers in the globalization process when western financial capital tries to dominate over functional capital of the other nations. Today the class content of Cold War rivalry does not show up.

Anyway, the book is a timely contribution that provides an important and valuable extension to contemporary political discourse and highly recommended to social thinkers interested in the current global political economy of military conflicts.

Received: October 1, 2018 Accepted: December 6, 2018

Author's information:

Mikhail V. Sinyutin — Dr. Sci. in Sociology, Professor; sinewtin@yandex.ru 